\title{
Ph.d.-studerende + bibliotek = @Philoteket
}

\author{
Kan man med events og et område på biblioteket \\ dedikeret til SDU's ph.d.-studerende bidrage til at øge \\ trivslen under ph.d.-forløbet? Ja, det mener vi faktisk \\ er lykkedes med ph.d.-caféer og Philoteket, som med \\ stabil drift og gode fysiske rammer skaber betingelser \\ for et bedre ph.d.-forløb.
}

Siden foråret 2017 har vi afholdt 15 ph.d.-caféer på Syddansk Universitetsbibliotek med det formål at give ph.d.-studerende input til at komme igennem deres 3-årige forskeruddannelse. Undervejs har vi lært meget om vores målgruppe og har måttet tilpasse os diverse udfordringer, ikke mindst siden foråret...

Idéen til at lave et nyt tilbud til ph.d.-studerende på Syddansk Universitet udsprang af en interesse for denne målgruppe, som er i en overgangsfase mellem at være studerende og forskere. Vi møder ph.d.-studerende i vores arbejde, både når vi underviser og vejleder i informationssøgning og til undervisning i ansvarlig forskningspraksis, og derfra ved vi, at der kan være mange udfordringer ved at træde ind i forskerverdenen.

En af de store udfordringer er alt det uudsagte: akademiske færdigheder og kompetencer, som du forventes at have eller tilegne dig i løbet af ph.d.-uddannelsen, men uden at det nødvendigvis er beskrevet eller tilbydes som kurser.
Det drejer sig f.eks. om forskningsformidling, tidsstyring og meget aktuelt: afholdelse af ph.d.-forsvar online. Desuden ved vi fra både APV'er og vores interviews med ph.d.-studerende, at mange føler sig ensomme og ikke får meget sparring i det daglige, hverken fra vejleder(e) eller kolleger. Disse indtryk fik os til at tænke nærmere over, hvordan vi som bibliotek kan bidrage til at ph.d.-studerende opnår disse færdigheder og derved gøre ph.d.processen lettere.

Vi har tidligere beskrevet, hvordan vi udviklede vores cafétilbud via interviews med 12 ph.d.-studerende fra SDU, som var i sidste halvdel af deres ph.d.-forløb [1]. Konklusionen på undersøgelsen var, at ph.d.-caféerne skulle være en blanding af en formel del med et oplæg og en mere uformel del, hvor man kunne netværke og dele erfaringer med andre ph.d.studerende.

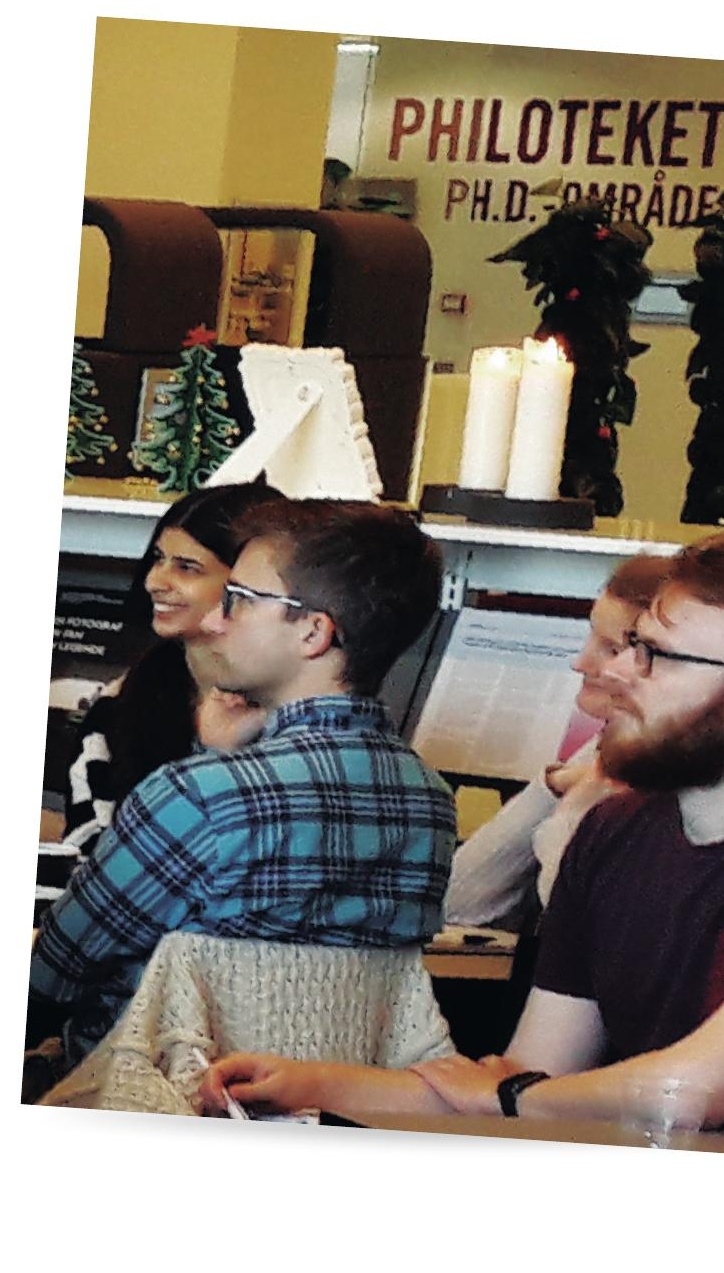




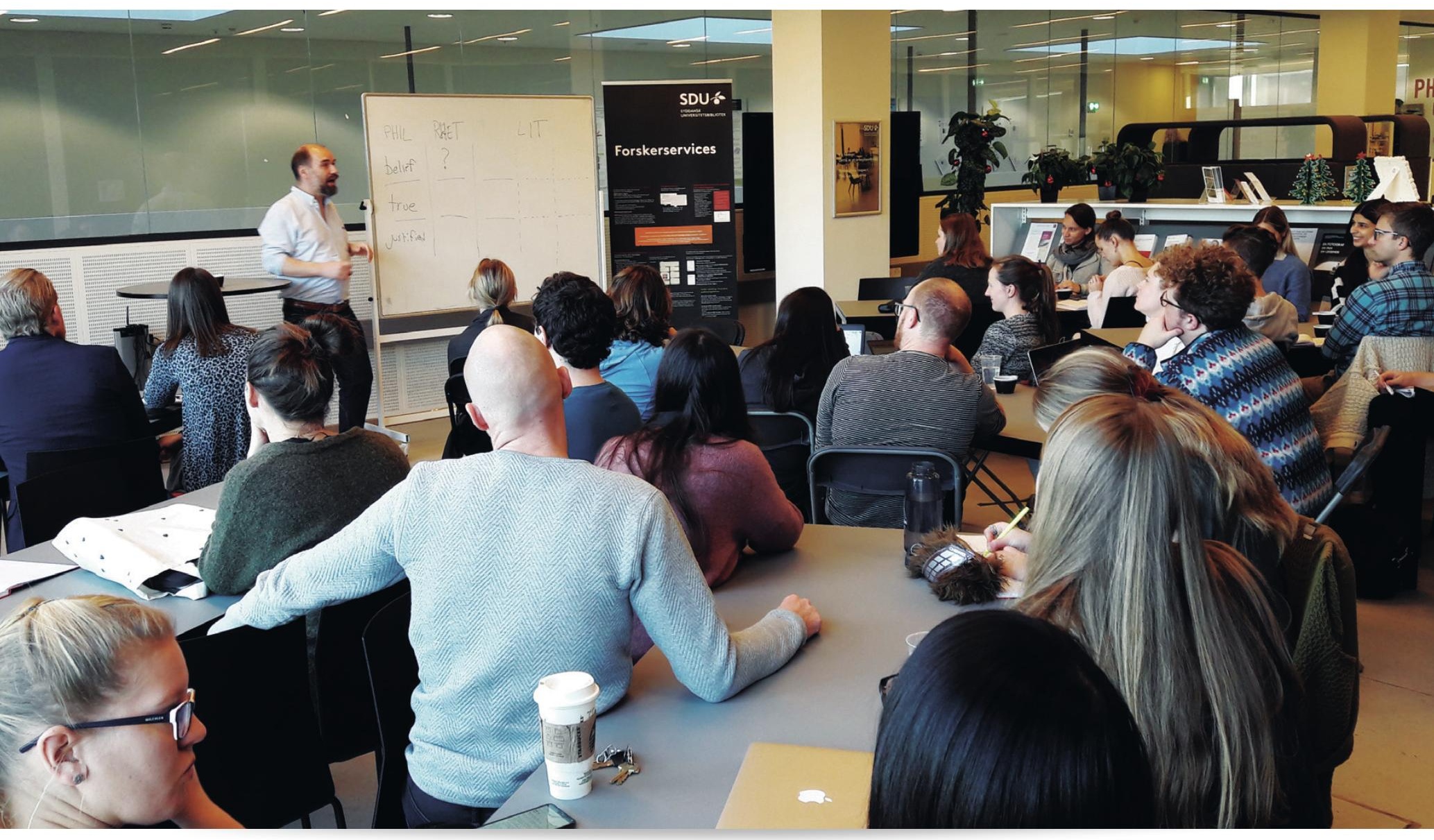

Desuden var det også et ønske at deltagelse var frivillig, der skulle altså ikke være tale om kursusaktivitet.

\section{Rammer og indhold}

Samtidig med opstarten på ph.d.-caféerne var det muligt at etablere et ph.d.-område på biblioteket, som har fået navnet Philoteket. Her kan man afholde præsentationer, prøveforsvar, møder, interviews eller få sig et afbræk fra et travlt fælleskontor. Det er muligt for de ph.d.-studerende at booke Philoteket, f.eks. afholder ph.d.-foreningen på SDU (PAUSD) deres bestyrelsesmøder og arrangementer her. Vi samarbejder i det hele taget meget med PAUSD: Vi får input til nye emner til ph.d.-caféerne, og de kan være med til at udbrede kendskabet til vores aktiviteter. Omvendt kan vi understøtte dem i at arrangere og afholde events, som til dels relaterer sig til vores, samt sikre stabilitet omkring deres aktiviteter.

Både faciliteter og events på biblioteket er med til at skabe en tryg ramme og skabe stabilitet omkring de ph.d.-studerende på SDU, som naturligt udskiftes hele tiden. Vi mener, at det er vigtigt at tilbyde et sted, hvor konkurrence og prestige er i baggrunden, og hvor det er tilladt at dele sine udfordringer under ph.d.-processen og få input fra andre i samme situation. Dette forsøger vi at sikre ved kun at lade ph.d.-studerende og postdocs deltage i ph.d.caféerne. Vi forsøger at skabe en uformel stemning ved at placere deltagerne ved borde og sørge for forplejning.

Udskiftningen i bestanden af ph.d.-studerende betyder også, at vi hele tiden skal være synlige og promovere os selv overfor nye ph.d-studerende. Invitationer til ph.d-caféer udsendes gennem fakulteternes ph.d.-skoler, men vi forsøger at komme i direkte kontakt med målgrupper og er derfor aktive på sociale medier og opfordrer de ph.d.-studerende til at følge os på Facebook ellerTwitter (@Philoteket) for at få de nyeste informationer om vores aktiviteter.

Vores interviewundersøgelse viste, at ensomhed var udbredt blandt ph.d.-studerende på humaniora, fordi de arbejder mere alene og ikke behøver møde op på arbejdspladsen hver dag, i modsætning til på naturvidenskab, hvor hovedparten laver laboratoriearbejde og arbejder i forskningsgrupper. Denne observation fik os til at tro, at ph.d-caféerne ville tiltrække mange ph.d.-studerende fra humaniora, men det har ikke været tilfældet. 


\section{FACTS OM PH.D.-CAFÉERNE}

\begin{tabular}{|l|l|}
\hline Frekvens & 2-3 events pr. semester \\
\hline Varighed & Ca. 2 timer \\
\hline Tidspunkt & Omkring frokosttid \\
\hline Første halvdel & Præsentation og diskussion \\
\hline Anden halvdel & Netværk og sparring \\
\hline Forplejning & Kaffe, thé og sandwich \\
\hline Kommunikation & $\begin{array}{l}\text { Invitationer udsendes via ph.d.-skoler, } \\
\text { opslag på Facebook og Twitter }\end{array}$ \\
\hline Oplægsholdere & Blanding af interne og eksterne \\
\hline Antal deltagere & 3-52, i gennemsnit 23 \\
\hline
\end{tabular}


I stedet er der flest deltagere fra naturvidenskab og ingeniørfagene. Vi er opmærksomme på at udvikle temaer og afviklingen af ph.d.-caféerne, så de er relevante og tilgængelige for alle fakulteter. Postdocs og andre yngre forskere er også interesserede i events omhandlende bredere emner som f.eks. karrieremuligheder. Det er vigtigt at bevare fokus på målgruppen, og at de opfatter Philoteket og ph.d-caféerne som et sikkert sted at diskutere også svære emner. Det kunne dreje sig om vejlederrelationen, eller hvordan ph.d.-studerende opfattes på deres institutter.

\section{Nye (Corona-)tider}

Coronanedlukningen i foråret havde naturligvis også stor betydning for vores muligheder for at afholde arrangementer. Vi arrangerede en virtuel ph.d-café midt i april: "Creating structure in chaotic times" for at få en fornemmelse af, hvordan de ph.d.-studerende klarede nedlukningen. Det var tydeligt, at der var behov for input til tidsstyring og for at møde andre ph.d.-studerende i samme situation. Derfor fortsatte vi med at lave online events og gennemførte derefter en ph.d.-café om tidsstyring med fokus på hjemmearbejde, som havde godt 50 deltagere. I juni måned lavede vi en virtuel ph.d.-café om at afholde sit ph.d.-forsvar online, en ny udfordring som man lige skulle kunne klare oveni selve forsvaret. 3 ph.d.-studerende, som netop havde forsvaret deres ph.d., holdt oplæg og delte ud af deres overvejelser og erfaringer med at præsentere online. Det var faktisk første gang, vi havde ph.d.-studerende som oplægsholdere, og det gav en god diskussion af emnet, og førte til mere omtale af vores arrangement hos målgruppen, fordi oplægsholderne promoverede ph.d.-caféen i deres netværk og på sociale medier.

Efter afholdelse af en del ph.d-caféer har vi nu erfaret, at emner som akademisk skrivning eller tidsstyring er meget populære, fordi man får et konkret udbytte, som også er med til at berettige, at man bruger tid på at tage til ph.d.café. Feedback fra de virtuelle ph.d-caféer har vist, at flere faktisk foretrækker dette format, da det ikke er så forpligtende som at deltage i et fysisk event. Selvom en del ph.d.-studerende føler sig ensomme, har mange det fint med at arbejde på denne måde og har ikke et socialt behov i arbejdsmæssig sammenhæng.

\section{Da SDU er en institution med 6} campusbyer, hvor der alle steder er ph.d.-studerende ansat, giver online events også flere mulighed for at deltage. Det gælder også under ophold ved andre forskningsinstitutioner under ph.d.-uddannelsen. I fremtiden har vi derfor planer om at veksle mellem fysiske og online events, da disse formater opfylder forskellige behov hos målgruppen.

Når man er ph.d.-studerende, får man ofte at vide, at det skal være en hård proces, og at ensomhed bare er et vilkår. Men efter vores opfattelse får man ikke forløst det fulde potentiale hos nutidens ph.d.-studerende under disse betingelser, og vi arbejder derfor på at gøre en forskel for ph.d.-studerende på SDU ved at tale åbent om udfordringerne. Ph.d.-caféerne bliver løbende evalueret for at få feedback på de afholdte events og idéer til nye emner. Nedenfor ses eksempler på tilkendegivelser:

\section{Eksempler på feedback og tilkendegivelser fra deltagere:}

- The social aspect related to the other phd students.

- I liked that there were concrete tips given as to how to write a good grant application. I also liked the atmosphere and that there were a mix of people from different faculties.

- Yesterday's PhD Café event was extremely relevant, and E. did a super job presenting

- Jeg vil bare rose jer for initiativet, det er en super god mulighed

- At blive klædt på til ph.d.-processen er guld værd

- I'm all by myself at the department. The café is a great chance to meet other PhD students

Denne artikel er skrevet med baggrund i et blogindlæg på The Hidden Curriculum [2].

\section{Referencer:}

1. Bredahl, L., Jacobsen, K. A., \& Husen, K.J. (2018). Barrierer for det gode ph.d.-forløb og udvikling af et cafétilbud i biblioteket. Dansk Universitetspædagogisk Tidsskrift, 13(25), 71-90. https://tidsskrift.dk/dut/article/view/96698

2. Jacobsen, K., Bredahl, L., \& Husen, K. J. (2020, Sep 22). Creating a safe space for dialogue for PhD students. https://drhiddencurriculum.wordpress.com/2020/09/22/creating-a-safe-space-for-dialogue-for-phd-students/ 